$$
\begin{aligned}
& \text { 分子動力学法による自由エネルギーを用いた } \\
& \text { アスファルテン分子とシリカ鉱物の吸着特性の評価 }{ }^{\dagger}
\end{aligned}
$$

石塚 師也* 梁 云峰** 松岡 俊文***,****

\title{
Evaluation of Adsorption Characteristics between an Asphaltene Molecule and Silica Through Free Energy Calculation by Molecular Dynamics Simulation
}

by

\author{
Kazuya ISHITSUKA*, Yunfeng LIANG** and Toshifumi MATSUOKA*******
}

\begin{abstract}
Asphaltene adsorption on silica surface plays an important role in wettability alternation in an oil reservoir and the durability of asphalt pavement. In this study, we investigated the relationship between asphaltene structure and adsorption characteristics via potential of mean force (PMF) by molecular dynamics simulation. We prepared six types of asphaltene molecules, and studied the adsorption Gibbs free energy on two different silica surfaces (e.g., hydrophilic and hydrophobic silica). In total, twelve PMFs between a single asphaltene molecule and silica were calculated. On both hydrophilic and hydrophobic silica surfaces, the calculated adsorption Gibbs free energy of asphaltene with a hydroxyl terminal was larger than the similar types of asphaltene without hydroxyl terminals because of hydrogen bonding between a hydroxyl terminal and silica surfaces. The adsorption Gibbs free energy of asphaltene with larger aromaticity was also large, while those of asphaltene with less aromaticity and no alkyl chain were small. Moreover, for all asphaltene molecules, the calculated adsorption Gibbs free energy is significantly larger for hydrophobic surface than hydrophilic one (by $8-54 \mathrm{~kJ} / \mathrm{mol}$ ). The underlying mechanism can be ascribed to the polarity difference of those two surface structures. This study shows a quantitative evaluation of the adsorption characteristics in different types of asphaltene and mineral surfaces.
\end{abstract}

\section{Key words:}

Asphaltene, Molecular dynamics simulation, Potential of mean force, Silica, Adsorption

\section{1 緒言}

アスファルテンは原油のうち, トルエンやベンゼン等 の芳香族炭化水素に可溶で, ヘプタン等の飽和炭化水素 に不溶な成分である ${ }^{1), 2)}$. 原油の生産においては, アスフ アルテンと鉱物の吸着現象は，岩石と油の濡れ性を変化 させるために原油の回収率に関係すると考えられている 3) 5). またアスファルテンは, 道路の舗装に広く用いられ る土木材料であるアスファルトの主要な成分であり，ア スファルトと骨材の混合物は広く道路舗装に用いられて いる，そのため，アスファルテンと鉱物の吸着強度はア スファルト舗装道路の耐久性を考える上でも重要となる 2),6).

これまでアスファルテンの分子構造は複数のタイプが 提案されている．ただし，共通する特徴としては多環芳 香族炭化水素であり，縮合環部分と，側鎖となるアルキ ル基からなり, 数パーセントの窒素や硫黄, 酸素等のへ テロ原子から構成されると考えられる ${ }^{77,8)}$. また，質量分
析等により, 質量は約 500-1000 Da であることが知られて いる ${ }^{9) 11) . ~}$

アスファルテンと鉱物の吸着強度の検討は, これまで 実験的な検討が主に成されてきた。これらの結果では, アスファルテンの化学的もしくは構造的特徵が吸着特性 と関連していることが示されている ${ }^{1)}$. 例えば, $\mathrm{X}$ 線光電 子分光法を用いた研究により, 吸着しているものはアス ファルテンの中でもへテロ原子を多く含むアスファルテ ンであることが示されている ${ }^{12)}$. また, 芳香族炭素分率 (Aromaticity) が多いアスファルテンの分子ほど吸着しや すいことも示されている 13),14). また，ヒドロキシル基や カルボキシル基，サルファイド基を多く含むアスファル テンも吸着しやすいことが知られている. 一方, アスフ アルテンの酸化によって一般的に生じるケトン基を含む アスファルテン分子はそれほど吸着しないことも示され ている ${ }^{15)}$. これらの先行研究は, 鉱物表面に吸着しやす いアスファルテン分子の特徴を示しているが，異なるア

$\dagger \quad$ 原稿受理 平成29年 7月10日 Received July 10,2017 C2018 The Society of Materials Science, Japan

* 北海道大学大学院 環境循環システム部門 テ060-8628 北海道札幌市北区

Division of Sustainable Resources Engineering, Hokkaido University., Kita-ku, Sapporo 060-8628.

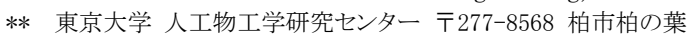

Research into Artifacts, Center for Engineering, The University of Tokyo., Kashiwanoha, Kashiwa 277-8568.

*** 正 会 員 公益財団法人 深田地質研究所 $\overline{1} 113-0021$ 東京都文京区本駒込

Fukada Geological Institute, Bunkyo-ku, Tokyo 113-0021.

**** 正 会 員 京都大学 学際融合教育研究センター $\bar{~} 615-8530$ 京都市西京区京都大学桂

Center for the Promotion of Interdisciplinary Education and Research, Nishikyo-ku, Kyoto 615-8530. 
スファルテンの分子構造や異なる実験条件，異なる鉱物 表面特性で実験が行われているため, アスファルテンと 鉱物の吸着強度の定量的な解明には至っていない. Long

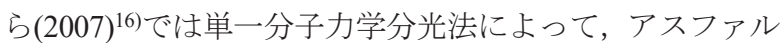
テンと雲母鉱物での吸着強度の測定が分子スケールで行 われているが，測定值には複数のアスファルテン分子が 凝集した影響が含まれている。このためアスファルテン の分子構造上の特徵が，鉱物への吸着特性へ及ぼす影響 を理解するには，鉱物表面上で単一種類の分子を用いた 理論的な評価が必要である.

本研究では, 分子動力学法によって得られる自由エネル ギーを用いて，アスファルテンの分子構造上の特性と鉱 物への吸着特性を定量的に評価する。これまでに, Headen and Boek (2010) ${ }^{17)}$ では，アスファルテン 1 分子とカルサイ 卜鉱物の吸着特性を平均力ポテンシャル（Potential of Mean Force: PMF）によって評価し，アスファルテン分子 がカルサイトに吸着した配置での自由エネルギーが妥当 な值となることを示した。本研究では，以下に示す 6 種 類の構造的特徴をもつアスファルテンに対して，シリカ 表面における PMF を計算する。これによって，アスファ ルテンの分子構造の差異によって生じるシリカ鉱物との 吸着特性の違いを定量的に明らかにする。シリカは石英 の約 97\%を占める鉱物であり，原油貯留層内を作ってい る砂岩層や，道路の舗装に骨材として用いられる砂利を 構成する一般鉱物である。また，シリカ表面には親水性 の特性を有する表面と，親油性シリカ表面を用意し，両 者の比較を行うことによって，表面性状の違いが吸着特 性に与える影響も検討する.

\section{2 手法および用いた分子モデル}

\section{$2 \cdot 1$ 自由エネルギーの評価方法}

親水性のシリカ表面は，シリカ表面をシラノール基で 飽和させることによって作成した。また，親油性シリカ 表面はシロキサン結合によって構成した（Fig.1, Table 1). また, 親油性および親水性シリカともに, 内部構造は $\alpha$ ク

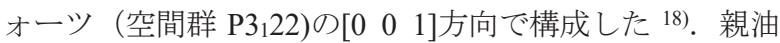
性・親水性シリカともに CLAYFF 力場 19)を用いてポテン シャルを計算した（Table 1). また，用いたシリカのサイ ズは, 親油性シリカの場合は, $[\mathrm{x}, \mathrm{y}, \mathrm{z}]=[3.0 \mathrm{~nm}, 2.6 \mathrm{~nm}, \sim 1.6$ $\mathrm{nm}]$ とし, 親水性シリカの場合は, $[\mathrm{x}, \mathrm{y}, \mathrm{z}]=[3.0 \mathrm{~nm}, 2.6 \mathrm{~nm}$, $\sim 1.2 \mathrm{~nm}]$ とした.

PMF は 2 種類の原子または物質の自由エネルギーをあ る反応軸上で表したものである 201,21). アスファルテンと シリカ表面間のPMF の最小值と両者が十分離れた位置で のPMF の差は吸着に関する自由エネルギーと解釈するこ とができる. PMF の計算方法としては, アンブレラサン プリング法が広く知られている 22),23)ので，本研究でもこ の手法を採用した。アンブレラサンプリング法は，ある 一方向（本研究では鉱物表面に直交する方向）に反応軸 をとり，反応軸に沿って，ポテンシャルにバイアスをか
Table 1 Atom parameters (sigma, epsilon for Lenard-Jones potential and charges) in hydrophilic and hydrophobic silica.

\begin{tabular}{c|ccc} 
Hydrophilic silica & Sigma $[\mathrm{nm}]$ & $\begin{array}{c}\text { Epsilon } \\
{[\mathrm{kJ} / \mathrm{mol}]}\end{array}$ & $\begin{array}{c}\text { Charge } \\
{[\text { electron }]}\end{array}$ \\
\hline $\mathrm{Si}$ & 0.3302027 & $7.7058^{*} 10^{-6}$ & 2.1000 \\
$\mathrm{O}$ & 0.3165541 & 0.65062872 & -1.0500 \\
O in OH terminals & 0.3165541 & 0.65062872 & -0.9500 \\
H in OH terminals & 0 & 0 & 0.4250 \\
\hline Hydrophobic silica & & & \\
\hline $\mathrm{Si}$ & 0.3302027 & $7.7058^{*} 10^{-6}$ & 2.1000 \\
$\mathrm{O}$ & 0.3165541 & 0.65062872 & -1.0500
\end{tabular}
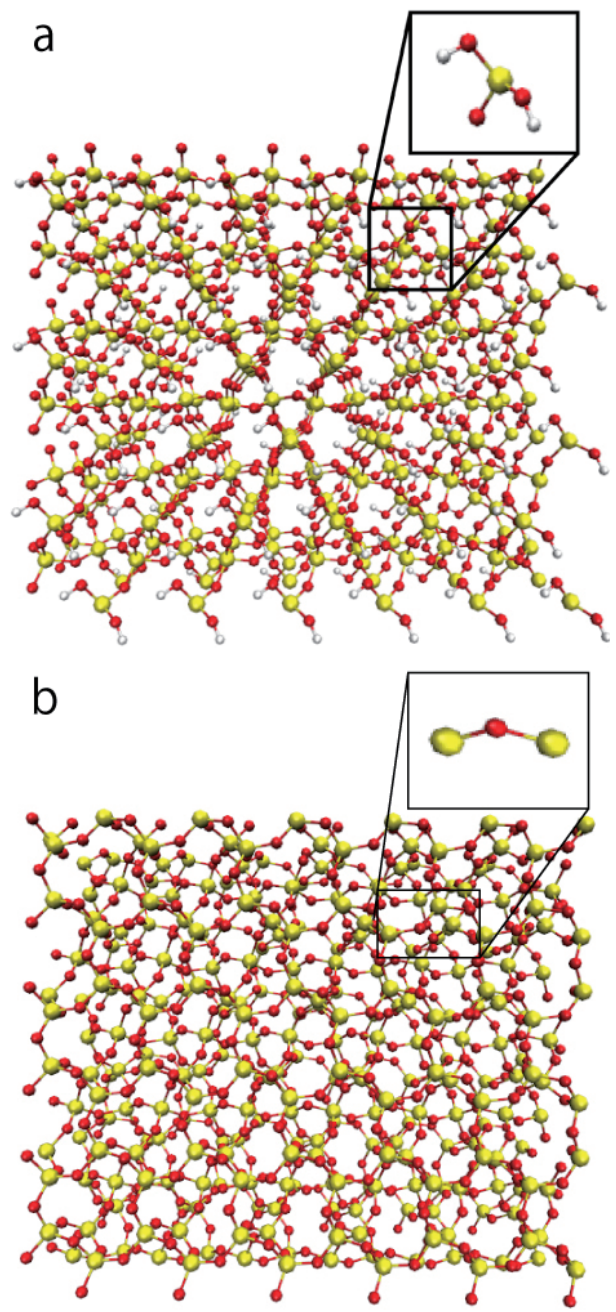

Fig. 1 (a) Hydrophilic silica used in this study. The surface is covered by hydroxyl silanol terminals. (b) Hydrophobic silica used in this study. The surface is covered by siloxane linkages. Yellow, red and white balls represent $\mathrm{Si}, \mathrm{O}$ and $\mathrm{H}$, respectively.

けることで，疑似的に安定な状態を反応軸上のある地点 に作り出す。本研究では, Weighted histogram analysis method（WHAM）を用いてアンブレラサンプリングを行 った。この方法は，以下で表されるハーモニックポテン シャルを用いる。

$$
w_{i}(\xi)=\frac{K_{i}}{2}\left(\xi_{i}-\xi_{i}^{c}\right)^{2}
$$

ここで，乡は反応軸を表し， $\xi_{i}^{c}$ は反応軸上のある位置を 
Table 2 Structural parameters of Asphaltene model molecules.

\begin{tabular}{c|cccccc} 
& Weight $[\mathrm{g} / \mathrm{mol}]$ & $\begin{array}{c}\text { Num of aromatic } \\
\text { carbons }\end{array}$ & $\begin{array}{c}\text { Num of aliphatic } \\
\text { carbons }\end{array}$ & Heteroatoms & Aromaticity & H/C \\
\hline $\mathrm{ASPa}$ & 712 & 28 & 24 & $\mathrm{~S}$ & 0.54 & 1.077 \\
$\mathrm{ASPb}$ & 708 & 32 & 20 & $\mathrm{~S}$ & 0.62 & 1 \\
$\mathrm{ASPc}$ & 726 & 28 & 24 & $\mathrm{O}, \mathrm{S}$ & 0.54 & 1.038 \\
$\mathrm{ASPd}$ & 728 & 28 & 24 & $\mathrm{O}, \mathrm{S}$ & 0.54 & 1.077 \\
$\mathrm{ASPe}$ & 726 & 20 & 32 & $\mathrm{~S}$ & 0.38 & 1.35 \\
$\mathrm{ASPf}$ & 442 & 28 & 7 & None & 0.80 & 0.63
\end{tabular}

表す. $w(\xi)$ は加えるポテンシャルを表し, 值は定数 $K$ に 比例する. PMF は以下の式に沿って, WHAM で得られた 系の確率分布 $P(\xi)$ から計算を行う.

$$
W(\xi)=-k_{B} T \ln \left(\frac{P(\xi)}{P\left(\xi_{0}\right)}\right)
$$

ここで， $k_{B}$ はボルツマン定数を表し， $\xi_{0}$ はPMF がゼロ となる反応軸上の任意の地点を表す．PMF が負であり， より小さい值を示すほど，吸着のギブス自由エネルギー が大きいため，より強く吸着していると解釈できる.

\section{$2 \cdot 2$ アスファルテン分子モデル}

本研究では, アスファルテンの分子モデルを作成する ために General Amber 力場を用いた. さらに Headen ら (2009) $)^{24)}$ によって提案され, Sedghiら（2013）25)によって 用いられているアスファルテンの分子構造を基本形

（ASPa）とした. この分子モデルは質量が $712 \mathrm{~g} / \mathrm{mol}$, 芳 香族炭素分率は $0.54,8$ つのベンゼン環と 3 つのシクロ環 を有し，側鎖には硫黄原子がある. 次にこの基本形に加 えて, Sedghi ら(2013)に従って, 構造が少し異なるアスフ アルテンの分子モデルとなる候補を 6 種類作成した (Fig. 2, Table 2). ASPb モデルが ASPa よりも芳香族炭素分率の 高いモデル，ASPc はケトン基を有するモデル，ASPd は ヒドロキシル基を有するモデル，ASPe は芳香族炭素分率 が小さいモデル，ASPf は側鎖がないモデルとして作成を した，地下に堆積した有機物は熱分解を起こし単純な炭 化水素に変化していくが, この続成作用が進むほど, H/C 比率が小さくなることが知られている．また，側鎖の短 いアスファルテン分子は石油起源よりも石炭起源のアス ファルテンに多く含まれることが知られている ${ }^{26)}$. それ ぞれの構造の特徴は Table 2 に示す.

\section{$2 \cdot 3$ シミュレーション概要}

まず親水性シリカ表面での吸着特性を計算するために アスファルテン分子とシリカの平衡状態の系を作成した. まず，アスファルテン 1 分子をシリカ表面上にランダム に配置し，エネルギー最小化を行った。このとき，系の サイズは, $[\mathrm{x}, \mathrm{y}, \mathrm{z}]=[3.0 \mathrm{~nm}, 2.6 \mathrm{~nm}, 10.0 \mathrm{~nm}]$ とした。続い て，NVTアンサンブルを用いて， $300 \mathrm{~K}$ の条件下で， 0.5 フェムト秒間隔で 2 ナノ秒間に対応寸る分子動力学法の 計算を行った，長距離にも作用することが知られている
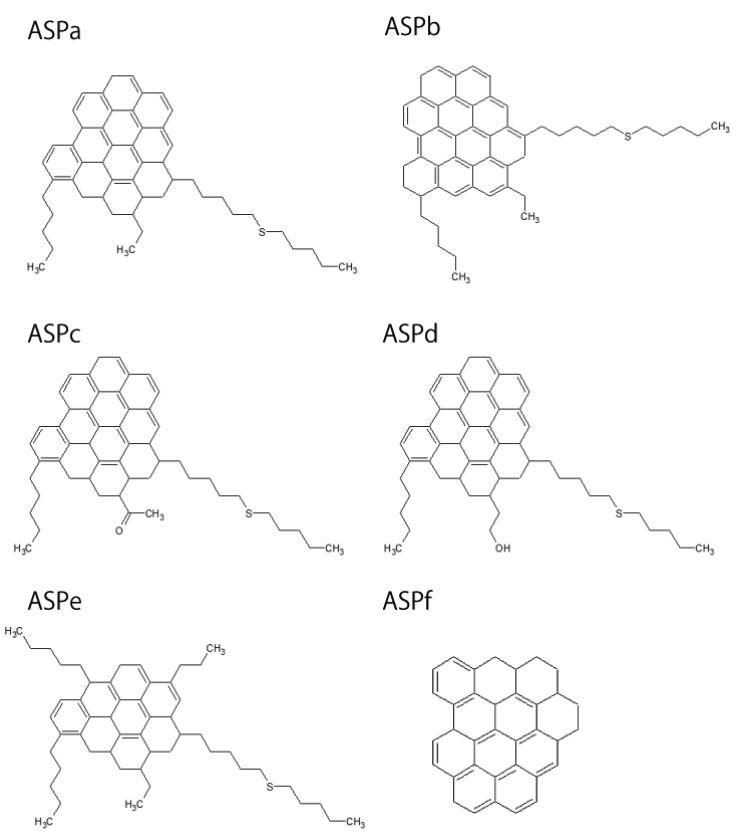

ASPf

Fig. 2 Asphaltene molecule models used in this study.

静電気力は Particle Mesh Ewald 法によって計算を行い, 主 に短距離において作用する分子間力はカットオフ距離を $1.1 \mathrm{~nm}$ として計算を行った. 周期境界条件は全方向に適 用した.

アンブレラサンプリング法では, シリカ表面に垂直の 方向に反応軸（引張り方向）をとり, 状態変化を計算し た. ハーモニックポテンシャルは $0.50 \mathrm{~nm}$ 間隔で計算を行 い, 40 回の計算を行った. そのため, 最終的な距離は 2.0 $\mathrm{nm}$ となる。これらの解析には GROMACS（ver. 5.1.4）を 用いた。

\section{3 分子構造とシリカ表面の自由エネルギー}

親水性シリカ表面における PMF の計算結果を Fig. 3, Table 3 亿示寸. 親水性シリカのうち, PMF の最小值が最 も小さい（ギブス自由エネルギーが最も大きい）アスフ アルテンの分子構造はヒドロキシ基を有する ASPd であ り, 最小值は-97.9kJ/mol となった。 また，基本形である ASPa の場合の最小值は-87.5 kJ/mol であった. すなわち, ASPd の吸着の自由エネルギーは ASPa と比較して, 絶対 
Table 3 Calculated adsorption Gibbs free energy, the distance at the minimum PMF and Gibbs free energy divided by the number of Carbon in asphaltene-hydrophilic silica case.

\begin{tabular}{c|ccc} 
& $\begin{array}{c}\text { Gibbs free } \\
\text { energy }[\mathrm{kJ} / \mathrm{mol}]\end{array}$ & $\begin{array}{c}\text { Distance } \\
{[\mathrm{nm}]}\end{array}$ & $\begin{array}{c}\text { Gibbs free energy } \\
\text { divided by the } \\
\text { number of Carbon } \\
{[\mathrm{kJ} / \mathrm{mol}]}\end{array}$ \\
\hline $\mathrm{ASPa}$ & -87.5 & 0.349 & -1.68 \\
$\mathrm{ASPb}$ & -89.7 & 0.445 & -1.73 \\
$\mathrm{ASPc}$ & -87.2 & 0.390 & -1.68 \\
$\mathrm{ASPd}$ & -97.9 & 0.366 & -1.88 \\
ASPe & -44.5 & 0.516 & -0.86 \\
ASPf & -61.4 & 0.377 & -1.75
\end{tabular}
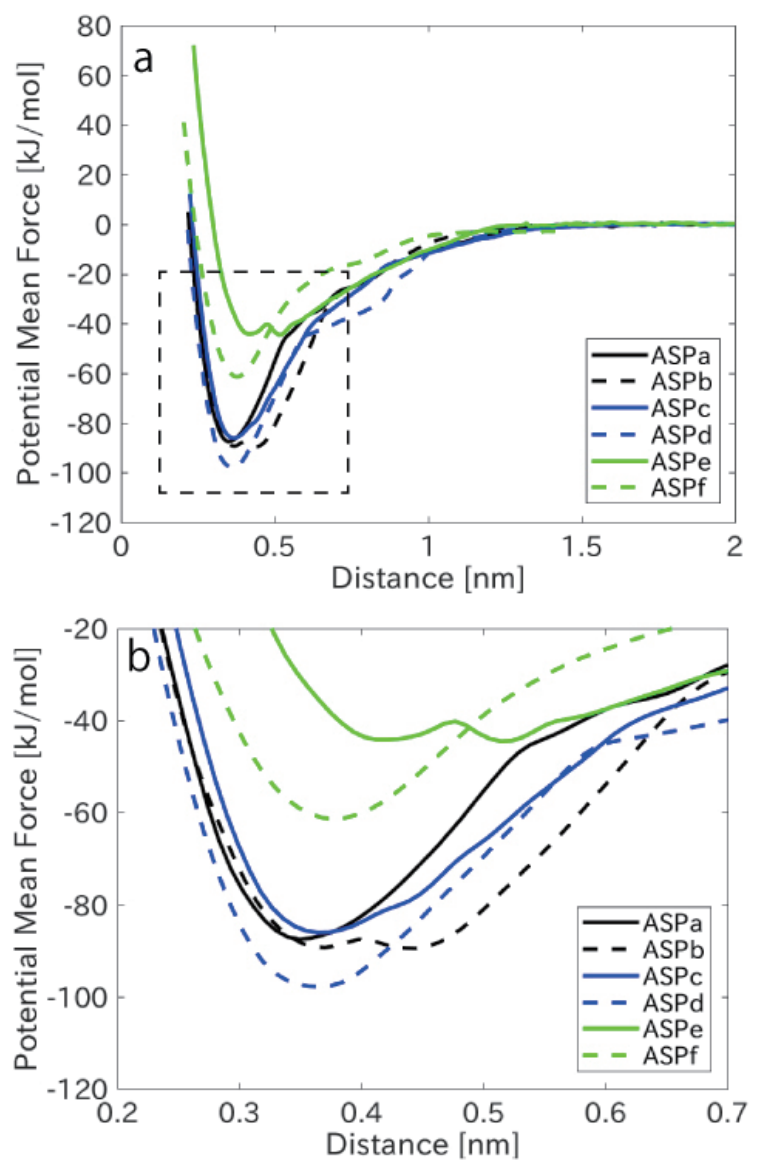

Fig. 3 Potential of mean force between the center-of-mass of an asphaltene molecule and hydrophilic silica surface. A black dashed line in a indicates the area of $b$.

值が約 11\%大きい（Table 3)。一方，ケトン基を有する ASPc のモデルの自由エネルギーは ASPa とほぼ同じで あった。これは側鎖の中でも特にヒドロキシル基がアス ファルテン分子のシリカ表面の吸着に重要な役割を担っ ていると言える。 (Fig. 3).

一方，縮合環数が少ない ASPe や側鎖の無い ASPfの自 由エネルギーは, $-44.5 \mathrm{~kJ} / \mathrm{mol}$ および-61.4 kJ/mol であった. ASPe はASPa と比較して, 自由エネルギーの絶対值が 43.0 $\mathrm{kJ} / \mathrm{mol}$ 小さくなった（Table 3)。これは, 縮合環数が小さ
ASPa $\quad \mathrm{ASPb}$

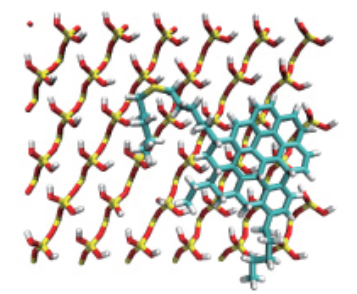

ASPC

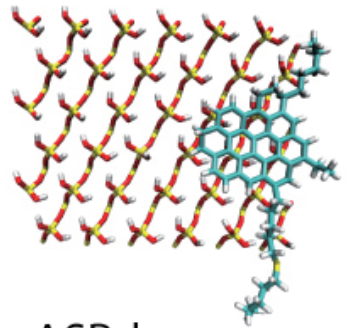

ASPd

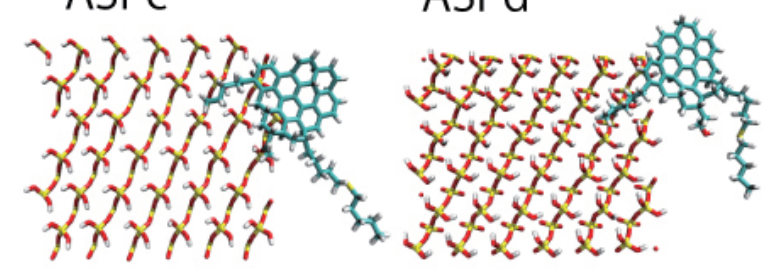

ASPe

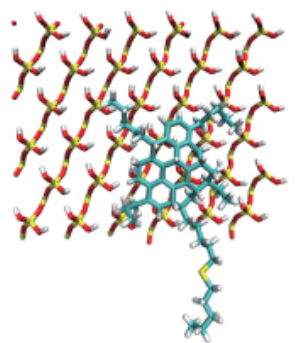

ASPf

Fig. 4 Configurations of an asphaltene molecule and hydrophilic silica at equivalent condition. For clarity, only top layer of the silica surface is shown. Blue, white, red and yellow balls in asphaltene molecules indicate $\mathrm{C}, \mathrm{H}, \mathrm{O}$ and $\mathrm{S}$, respectively.

いために, アスファルテン分子とシリカ表面の吸着強度 が低下したためと考えられる.また，ASPf は ASPa と比 較して, 自由エネルギーの絶対值が $26.1 \mathrm{~kJ} / \mathrm{mol}$ 小さくな つたが，これは原子数が小さい影響もあると考えられる. 自由エネルギーを炭素数で割つた值を Table 3 に示すが, ASPfの值は-1.75 であり, 絶対值は 2 番目に大きい. これ は，炭素数に比べて，吸着の自由エネルギーが大きいこ とを表しており，ASPfの芳香族炭素分率が他より大きい ためであると考えられる。

加えて, PMF の最小值が表れる距離を Table 3 に示した が，自由エネルギーとの相関は見られなかった。ただし， 側鎖が縮合環の複数の位置に分布している ASPe の距離 は他のモデルと比較して著しく大きく $(0.516 \mathrm{~nm})$, アル キル基側鎖の立体配置による影響が示唆される.

以上, 本研究の解析において, 吸着の自由エネルギー が大きい順に ASPd $>\mathrm{ASPb}>\mathrm{ASPc}=\mathrm{ASPa}>\mathrm{ASPf}>\mathrm{ASPe}$ となった。この順番は, フーリエ変換赤外分光高度計 (FT-IR）によって常温常圧下で計測されたシリカの吸着 特性結果 15) と整合的である。この実験では，複数の芳香 族炭化水素の乾燥したシリカ表面での吸着のしやすさに ついて評価しており，フェノール >ベンゾフェノン>ピ レンの順に吸着しやすいことを示した ${ }^{15)}$. この研究結果 は，ヒドロキシル基の吸着性の高さや側鎖が無い場合の 


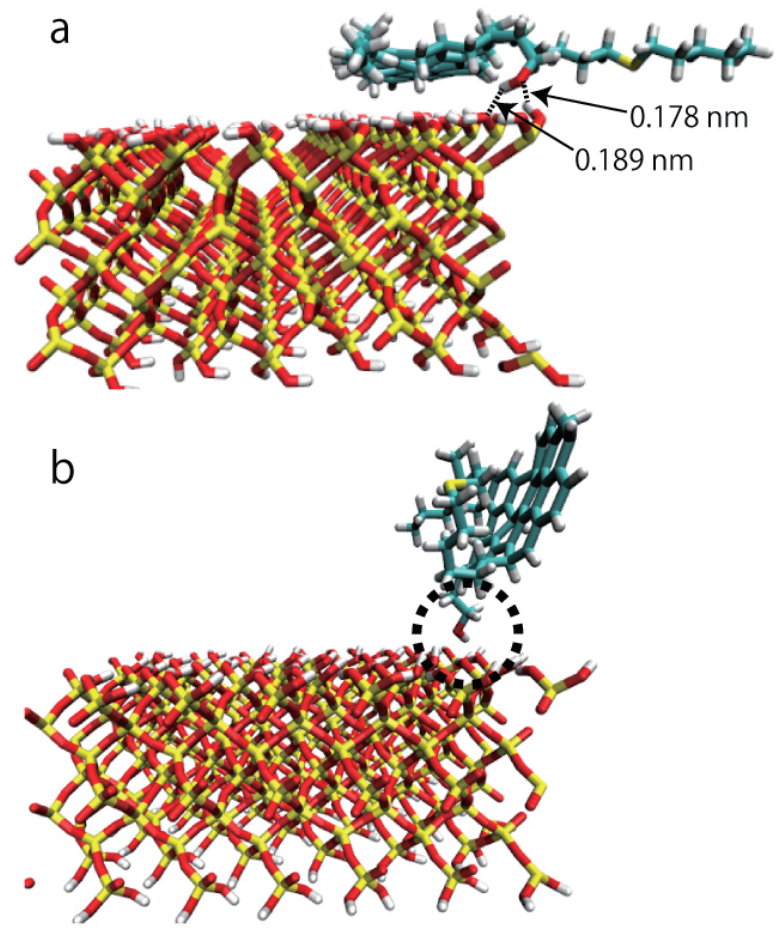

Fig. 5 Configurations of ASPd model. (a) A configuration at the distance of minimum PMF. (b) A configuration at the distance of about $0.8 \mathrm{~nm}$ from hydrophilic silica surface.

吸着性の低さを表しており，本研究における $\mathrm{ASPd}>\mathrm{ASPc}>\mathrm{ASPf}$ と言う関係に対応すると考えられる.

上述のように, PMF の最小值やその位置はアスファル テンの分子モデルによって異なる。ただし，いずれのモ デルにおいても，PMF が最小值を示寸距離では，縮合環 部分はシリカ表面とほぼ平行の形をしていることが分か った (Fig. 4, Fig. 5a). また，アルキル基側鎖は開いた形, 即ちシリカ表面と相互作用する形で平衡状態に達してい る. 最も吸着している状態では，官能基も含めたアスフ アルテン分子とシリカが多くの面積で接しており，アス ファルテンの分子構造による影響が最大限表れている状 況と示唆される。一方で，距離が離れるにつれ，アスフ アルテンとシリカ表面は直交するような形状を示すよう になった（例えば，Fig. 5b).

異なるモデルの PMF の形状を比較すると，2つの特徵

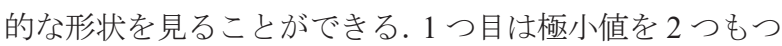
形状 (ASPb および $\mathrm{ASPe})$ である. ASPb の場合は $0.38 \mathrm{~nm}$ および $0.45 \mathrm{~nm}$ 付近に極小值があり, ASPe の場合は, 0.41 $\mathrm{nm}$ および $0.52 \mathrm{~nm}$ 付近に極小值がある (Fig. 3)。これら の比較的近い距離にある極小值を示寸距離において，ア スファルテン分子の縮合環はシリカ表面とほぼ平行な形 状をしている。このような PMF を示寸構造は 2 箇所安定 な領域があると言える。もう 1 つとしては, ASPd の 0.60 $\mathrm{nm}$ から $0.80 \mathrm{~nm}$ 付近において, PMF の傾きが一時的に緩 やかになっている位置である (Fig. 3)。この位置ではアス ファルテンの縮合環とシリカ表面は直交した配置になっ ている.アスファルテン分子同士の凝集においても，ア
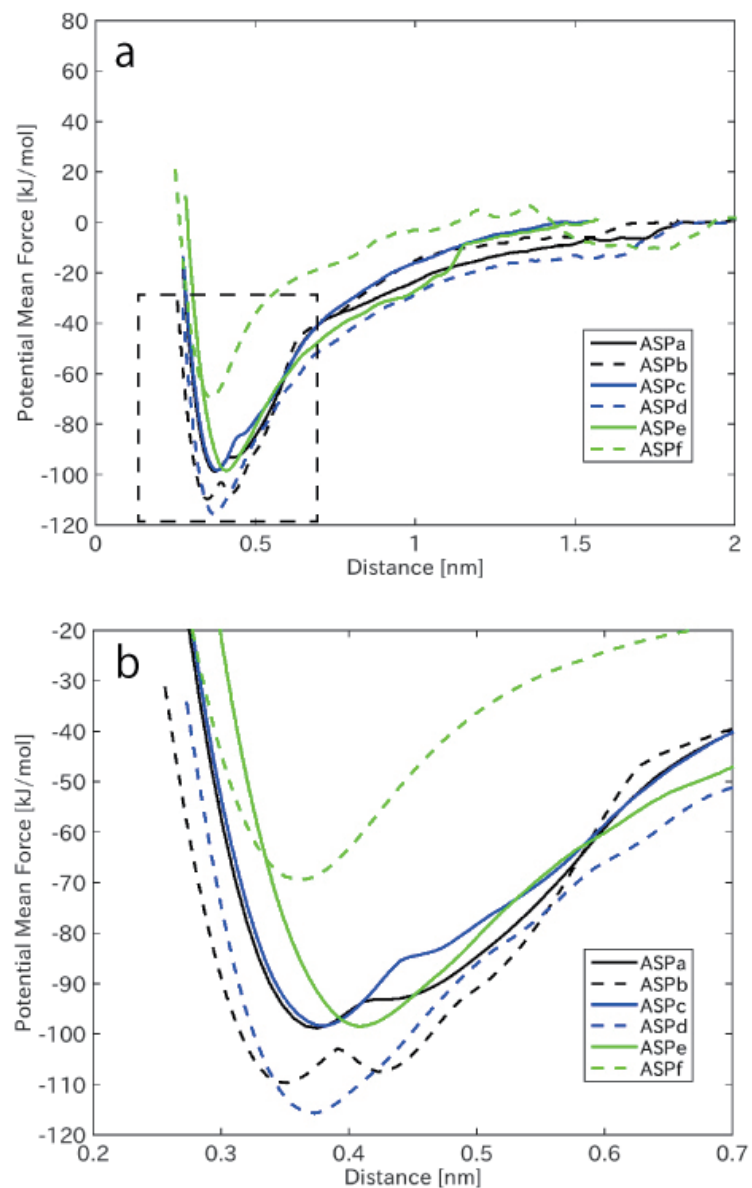

Fig. 6 Potential of mean force between the center-of-mass of an asphaltene molecule and hydrophobic silica surface. A black dashed line in a indicates the area of $b$.

スファルテン分子同士が平行になる場合だけでなく, 直 交した配置になる場合も凝集を起こす安定な配置として 知られている ${ }^{25}$. 特に ASPd の場合は, この距離におけ る分子の立体的配置によって，ヒドロキシル基がシリカ 表面を向いて位置する配置をとる（Fig. 5b)。この配置に 伴い吸着の自由エネルギーが大きくなるため，一時的に 緩やかな傾きをもつPMF が表れることと考えられる.

\section{4 アスファルテンとシリカ表面の幾何学的配置}

分子スケールにおいて, 各官能基や縮合環が与える影 響を解析するために，アスファルテンの分子モデルの質 量中心とシリカとの距離を計算した. ASPa モデルについ て計算したところ, 質量中心と親水性シリカ表面にある シラノール基の水素原子との最近接距離は, $0.395 \mathrm{~nm}$ で あった。一方，PMF の最小值が最も小さかった ASPd モ デル（ヒドロキシル基を有する）では，質量中心とシリ カ表面のシラノール基の水素原子との最近接距離は 0.384 $\mathrm{nm}$ であり, ASPa モデルよりも小さな值を示すことが分 かった，特にヒドロキシル基の水素原子，酸素原子はそ れぞれ親水性シリカ表面の酸素原子および水素原子の方 向を向き,これらの距離は $0.189 \mathrm{~nm}, 0.178 \mathrm{~nm}$ であった 
Table 4 Calculated adsorption Gibbs free energy, the distance at the minimum value and Gibbs free energy divided by the number of Carbon in asphaltene-hydrophobic silica case

\begin{tabular}{c|ccc} 
& $\begin{array}{c}\text { Gibbs free } \\
\text { energy [kJ/mol] }\end{array}$ & $\begin{array}{c}\text { Distance } \\
{[\mathrm{nm}]}\end{array}$ & $\begin{array}{c}\text { Gibbs free energy } \\
\text { divided by the } \\
\text { number of Carbon } \\
{[\mathrm{kJ} / \mathrm{mol}]}\end{array}$ \\
\hline $\mathrm{ASPa}$ & -98.8 & 0.375 & -1.90 \\
$\mathrm{ASPb}$ & -109.7 & 0.352 & -2.11 \\
$\mathrm{ASPc}$ & -98.4 & 0.381 & -1.89 \\
$\mathrm{ASPd}$ & -115.7 & 0.373 & -2.23 \\
$\mathrm{ASPe}$ & -98.5 & 0.407 & -1.89 \\
$\mathrm{ASPf}$ & -69.5 & 0.361 & -1.99
\end{tabular}

(Fig. 5a).これは，アスファルテン分子のヒドロキシ ル基と親水性シリカ表面で水素結合が形成されているこ とを示唆しており，この水素結合のためにアスファルテ ン分子はシリカ表面により強く吸着していると考えられ る.一方，ASPeの質量中心と親水性シリカのシラノール 基の水素原子との最近接距離は，0.432 nm であり，ASPa よりも $0.037 \mathrm{~nm}$ 大きな值であった.さらに, $\mathrm{ASPb}$ の質量 中心とシリカの水素原子との最近接距離は $0.392 \mathrm{~nm}$ であ り，ASPaよりわずかではあるが $(0.003 \mathrm{~nm})$ 小さい值で あった。

$\mathrm{ASPa}, \mathrm{ASPb}, \mathrm{ASPe} の$ 構造的特徽は主に芳香族炭素分率 の違いであり，芳香族炭素分率が大きいほど，シリカ表 面に近い位置で吸着していることが分かる．これらのこ とから，アスファルテン分子を構成している縮合環の割 合が吸着距離に影響している可能性がある。また，ASPf のモデルにおいては，親水性シリカのシラノール基の水 素原子との最近接距離は， $0.292 \mathrm{~nm}$ であり，6つのアスフ アルテンの分子モデルの中で最も小さい值を示した. ASPf の縮合環数は ASPa と同じであるが，側鎖が無いた めに, 最近接距離が小さくなったと考えられる. ただし, 距離が小さいほど吸着強度が強いわけではなく, 上述の ように ASPe や ASPfのモデルはシリカ表面により近い箇 所で吸着しているものの，自由エネルギーは小さい，

\section{5 親油性シリカ表面での自由エネルギ一}

シリカの表面性状と吸着強度との違いを調べるため, 親油性シリカ表面においても，PMF を計算した（Fig. 6, Table 4)。 その結果，基本形である ASPa モデルの自由エ ネルギーは， $-98.8 \mathrm{~kJ} / \mathrm{mol}$ であった。 また，親水性シリカ の場合と同様に, 他のモデルと比べて, ASPb および ASPd モデルの自由エネルギーが大きいことが分かった：その 中でも，ASPd モデルの自由エネルギーの值が最も大きく 值は-115.7 kJ/mol であった。この值は，絶対值を比較した 際，同じモデルの親水性シリカの場合（-97.9 kJ/mol）よ りも $17.8 \mathrm{~kJ} / \mathrm{mol}$ 大きい值である. 同様に, 他のアスファ ルテンモデルにおいても, 親油性シリカにおける自由エ ネルギーは親水性シリカと比べて大きかった，例えば，
ASPa の親油性シリカの值（-98.8 kJ/mol）の絶対值は，親 水性シリカの值 $(-87.5 \mathrm{~kJ} / \mathrm{mol})$ の絶対值より $11.3 \mathrm{~kJ} / \mathrm{mol}$ 大きかった。 また，親油性シリカと親水性シリカの值で 最も大きな変化が見られたのは ASPe であり, 親油性シリ 力を用いたとき值 $(-98.5 \mathrm{~kJ} / \mathrm{mol})$ の絶対值は，親水性シ リカを用いたときの值 $(-44.5 \mathrm{~kJ} / \mathrm{mol})$ の絶対值と比較し て，54.0kJ/mol 大きい，一方，最も変化が小さかったのは ASPf であり, ASPf の親油性シリカを用いたときの值 (-69.5 kJ/mol) の絶対值は，親油性シリカを用いたとき の值 $(-61.4 \mathrm{~kJ} / \mathrm{mol})$ の絶対值と比べて, $8.1 \mathrm{~kJ} / \mathrm{mol}$ だけ大 きい.

吸着強度は異なるものの，官能基等が与える影響は, 親水性シリカと親油性シリカで同様の傾向が見られた。 例えば， $\mathrm{ASPb}$ の自由エネルギーが大きい值を示したが, これは, 親水性シリカ同様に, 芳香族炭素分率が吸着強 度に与える影響を示唆している。また，ケトン基を有す る ASPc モデルは ASPa モデルの自由エネルギーほぼ変わ らず，親水性シリカと同様にケトン基は吸着に大きな影 響を及ぼさないと言える。また，親水性シリカの場合と 同様に，ASPfの自由エネルギーの絶対值は，他の自由エ ネルギーの絶対值よりも小さい值を示したが，自由エネ ルギーを炭素原子数で割った值の絶対值は 2 番目に大き な值となった．これも ASPfの芳香族炭素分率が大きいた めと考えられる (Fig. 6).

\section{6 結 言}

本研究では, アスファルテンの分子構造が異なる 6 種 類のモデルを用いてシリカ鉱物上の自由エネルギーを 計算することで, アスファルテンの分子構造とシリカ鉱 物の吸着強度を定量的に評価した. その結果, ヒドロキ シル基を有するアスファルテン分子の吸着強度は同様 の構造を有するがヒドロキシル基をもたないアスファ ルテン (ASPa) と比べて $12.4 \mathrm{~kJ} / \mathrm{mol}$ 大きくなることが 分かった．平衡状態における分子の配置を調べたところ， ヒドロキシル基と親水性シリカ表面では水素結合が形 成されており，この官能基の特性が吸着強度を高めてい ると考えられる。 また, 縮合環の数や芳香族炭素分率が 大きくなるにつれて, 吸着強度が大きくなる傾向が見ら れた。一方，ケトン基は，シリカ表面においてあまり吸 着強度に影響を及ぼさないことが示された。また，親油 性シリカと親油性シリカを比較したところ, 同じアスフ アルテンの分子構造において, 親油性シリカの自由エネ ルギーの方が $8-54 \mathrm{~kJ} / \mathrm{mol}$ ほど大きい值となった。これ は，親水性シリカ表面と親油性シリカ表面の極性の違い と考えられる.ただし，親油性シリカ表面においても， 親水性シリカと同様に，ヒドロキシル基を有するアスフ アルテン分子や縮合環数の多いアスファルテン分子に おいて吸着強度が高い傾向が見られた。

本研究の一部は JSPS 科研費 17K06988 および 
24246148 から支援を頂きました。ここに記して感謝致し ます。

\section{参 考 文 献}

1) J. J. Adams, "Asphaltene adsorption, a literature review", Energy and Fuels, Vol.28, pp.2831-2856 (2014).

2) J. Speight, in "Asphalt materials science and technology" (2015) Elsevier.

3) M. Vafaie-Sefti and S. A. Mousavi-Dehghani "Application of association theory to prediction of asphaltene deposition: Deposition due to natural depeletion and miscible gas injection processes in petroleum reservoirs", Fluid Phase Equilibria, Vol.247, No.1-2, pp.182-189 (2006).

4) J. L. M. Cruz, F. J. Arg $\ddot{u}$ elles-Vivas, V. Matias-Perez, C. A. Duran-Valencia and S. Lopz-Ramirez "Asphaltene-induced precipitation and deposition during pressure depletion on a porous medium: An experimental investigation and modeling approach", Energy Fuel, Vol.23, No.11 pp.5611-5625 (2009).

5) R. Z. Syunyaev, R. M. Balabin, I. S. Akhatov and J. O. Safieva "Adsorption of petroleum asphaltenes onto reservoir rock sands studied by near-infrared spectroscopy", Energy Fuel, Vol.23, No.3 pp.1230-1236 (2009)

6) C. W. Curtis, K. Ensley and J. Epps "Fundamental properties of asphalt-aggregate interactions including adhesion and adsorption", Strategic Highway Research Program (1993).

7) O. C. Mullins, "The modified Yen model", Energy Fuels, Vol.24, pp.2179-2207 (2010).

8) O. C. Mullins, A. E. Pomerantz, J. Orbulescu, J. C. Edwards "Advances in asphaltene science and the yen-mullins model”, Energy Fuels, Vol.26, pp.3986-4003 (2012).

9) K. Qian, K. E. Edwards, M. Siskin, W. N. Olmstead A. S. Mennito, G. J. Dechert and N. E. Hoosain "Desorption and ionization of heavy petroleum molecules and measurement of molecular weight distributions", Energy Fuel, Vol.21, pp.1042-1047 (2007).

10)A. R. Hortal, P. M. Hurtado, B. Martinez-Haya and O. C. Mullins, "Molecular weight distributions of coal and petroleum asphaltenes from laser desorption ionization experiments", Energy Fuel, Vol.21, pp.2863-2868 (2007).

11) H. Sabbah, A. L. Morrow, A. E. Pomerantz and R. N. Zare "Evidence for island structures as the dominant architechture of asphaltenes", Energy Fuel, Vol.25, pp.1597-1604 (2011)

12) A. Cosultchi, R. Rossbach and I. Hernandez-Calderon "XPS analysis of petroleum well tubing adherence", Surf. Interface Anal., Vol.35, No.3, pp.239-245 (2003).

13) Y. Tu, J. Woods, J. Kung, T. McCraken, L. Kotlyar, D. Kingston, and D. Mingzhe, "Adsorption of SARA fractions from heavy oil and bitumen on Kaolinite", Clay Sci., Vol.12, pp.194-198 (2006a).

14) Y. Tu, J, Kung, T. McCraken, L. Kotlyar, D. Kingston and B. Sparks, "Effect of clay particle size on the adsorption of a pentane insoluble bitumen fraction", Clay Sci., Vol.12, pp.194-198 (2006b).

15) C. W. Curtis, D. J. Clapp, Y. W. Joen and B. M. Kiggundu, "Adsorption of model asphalt functionalities, AC-20, and oxidized asphalts on aggregate surfaces" Transportation Research Record, No.1228, pp.112-127 (1989).

16) J. Long, Z. Xu and J. H. Masliyah "Single molecule force spectroscopy of asphaltene aggregates" Langmuir, Vol.23, pp.6182-6190 (2007).

17) T. F. Headen and E. S. Boek, "Potential of mean force calculation from molecular dynamics simulation of asphaltene molecules on a calcite surface", Energy Fuel, Vol.25, No.2, pp.499-502 (2010).

19) R. T. Cygan, J. J. Liang and A, G. Kalinichev, "Molecular models of hydroxide, oxyhydroxide, and clay phases and the development of a general force field", J. Phys. Chem. B, Vol.108, pp.1255-1266 (2004).

18) Y. Liang, S. Tsuji, J. Jia, T. Tsuji and T. Matsuoka, "Modeling $\mathrm{CO}_{2}$-water-mineral wettability and mineralization of carbon geosequentration", Acc. Chem. Res., Vol.50, pp.1530-1540 (2017).

20) J. G. Kikwood, "Statistical mechanics of fluid mixtures" The Journal of Chemical Physics, Vol.3, No.300 (1935).

21) B. Roux, "The calculation of the potential of mean force computer simulations", Computer Physics Communications, Vol.91, pp.275-282 (1995).

22) S. Kumar, D. Bouzida, R. H. Swendsen, P. A. Kollman and J. M. Rosenberg, "The weighted histogram analysis method for free-energy calculations on biomolecules. I. the method" Journal of Computational Chemistry, Vol.13, No.8, pp.1011-1021 (1992).

23) J. S. Hub, B. L. de Groot and D. van der Spoel, "g_wham - A free weighted histogram analysis implementation including robust error and autocorrelation estimates" Journal of Chemical Theory and Computation, Vol.6, pp.3713-3720 (2010).

24) T, F. Headen, E. S. Boek and N. T. Skipper, "Evidence for asphaltene nanoaggregation in toluene and heptane from molecular dynamics simulations", Energy Fuel, Vol. 23, pp.1220-1229 (2009).

25) M. Sedghi, L. Goual, W. Welch and J. Kubelka, "Effect of Asphaltene Structure on Association and Aggregation using Molecular Dynamics", The Journal of Physical Chemistry B, Vol.117, pp.5765-5776 (2013).

26) G. V. Chilingarian and T. F. Yen "Bitumen, asphalt and tar sands", Elsevier Scientific Publishing Company (1978). 